\title{
Conceito e Natureza Jurídica do Feminicídio ${ }^{1}$
}

Ythalo Frota Loureiro ${ }^{2}$

\section{RESUMO}

feminicídio é crime de homicídio qualificado de natureza objetiva, cometido contra mulher, por razões da condição de sexo feminino. O feminicídio foi criado para combater a violência doméstica e familiar contra a mulher e o menosprezo ou a discriminação à condição de mulher. O feminicídio resulta da ideologia de que o machismo e o poder se sobressaem como instrumentos de dominação e subjugação da mulher pelo homem. O Brasil é um dos países que mais se matam mulheres no Mundo. O feminicídio é circunstância de natureza objetiva por se tratar de situação ou qualidade pessoal da mulher. O feminicídio não se confunde com os motivos do crime, pois se trata de violência estrutural e institucionalizada. O Ministério Público deve incorporar a perspectiva de gênero nos casos de feminicídio para reforçar a efetividade da Lei Maria da Penha (Lei 11.340, de 2006).

Palavras-chaves: Feminicídio. Ministério Público. Tribunal do Júri.

\section{INTRODUÇÃO}

O feminicídio é uma modalidade de homicídio qualificado criada pela Lei 13.104, de 9 de março de 2015. O feminicídio ocorre quando o crime envolve violência doméstica e familiar; ou menosprezo ou 
discriminação à condição de mulher ${ }^{3}$.

A Lei 13.104/2015 ainda estabeleceu o aumento de 1/3 (um terço) até a metade se o crime for praticado durante a gestação ou nos 3 (três) meses posteriores ao parto. O aumento vale também quando o crime for praticado contra pessoa menor de 14 (catorze) anos, maior de 60 (sessenta) anos ou com deficiência; e quando cometido na presença de descendente ou de ascendente da vítima ${ }^{4}$. O aumento de pena é devido a circunstâncias que nitidamente tornam mais grave a conduta, impedindo que o julgador possa realizar interpretações "solipsistas", obrigando-o a aplicar punição mais gravosa.

A nova lei ainda alterou o art. $1^{\circ}$, inciso I, da Lei no 8.072 , de 25 de julho de 1990, para estabelecer o feminicídio como crime hediondo, portanto, sujeito a regime de cumprimento de pena diferenciado e mais gravoso ${ }^{5}$.

Ocorre que estas informações extraídas da lei não esclarecem, em sua totalidade, os motivos para criação do feminicídio e, tão pouco, o seu conceito e sua natureza jurídica.

Como se verá, a ausência de estudos mais aprofundados sobre o assunto tem levado juristas e manualistas a realizarem premissas e conclusões equivocadas. Objetivamos assim, discorrer acerca do feminicídio, seu conceito e natureza jurídica, e a importância de seu estudo no combate à violência de Gênero.

\footnotetext{
3 Art. 121, $2^{\circ}-\mathrm{A}$, incisos I e II, do Código Penal. 4 Art. $121, \S 7^{\circ}$, incisos I, II e III, do CP

5 Em verdade, como defendem Sapori e Soares (2014), a legislação brasileira não pune com severidade o homicida, dado que o tempo de aprisionamento máximo (20 anos) é muito baixo em relação a expectativa e vida de 73 anos de idade. Para eles, "Punir os homicidas com a devida severidade é fundamental para institucionalizar uma cultura de paz no Brasil. Porém, o custo de assassinar é muito baixo no Brasil, mesmo quando o culpado é identificado, indiciado, julgado, condenado e preso, uma raridade. Esse fato contribui para disseminação da violência. Os impulsos agressivos dos indivíduos encontram um contexto favorável, em que a punição é relativamente branda." (SAPORI;SOARES, 2014, p.96). Assim, o combate a criminalidade, e, em especial, ao crime de homicídio, é uma medida que vai além da própria punição, mas demanda o aumento dos índices de descoberta de autoria, o processamento e o julgamento dos processos em tempo razoável, para que o sistema criminal recupere sua capacidade de dissuadir a prática de homicídios. Em se tratando de feminicídios, suas peculiaridades demandam estratégias ainda mais específicas e mais sofisticadas, pois, como se verá mais adiante, se trata de crime mais ligado a favores culturais e psicológicos, como o machismo e a misoginia.
} 


\section{JUSTIFICATIVA PARA CRIAÇÃO DO FEMINICÍDIO}

O feminicídio é resultado do Projeto de Lei do Senado n² 292 , de $2013^{6}$. A redação original estabelecia o feminicídio como homicídio cometido contra a mulher por razões de gênero feminino. A expressão "por razões de gênero feminino" foi substituída "por razões da condição de sexo feminino", durante a tramitação do projeto na Câmara dos Deputados ${ }^{7}$, alcançando, assim, sua redação final.

Apesar de ter desagradado aqueles que defendiam a manutenção da expressão "por razões de gênero feminino", a redação final ("em razão da condição de sexo feminino") não prejudica os objetivos do projeto. Pelo contrário, a redação final torna mais fácil a compreensão do feminicídio pelos jurados e juízes leigos, dos quais não se exige conhecimentos jurídicos e técnicos aprofundados. A expressão "gênero feminino" poderia causar mais dificuldades no momento de explicar e perplexidades no momento de compreender.

De qualquer modo, a definição da expressão utilizada na redação é estabelecida no art. 121, §2-A, do Código Penal, ou seja, quando envolver violência doméstica e familiar, ou menosprezo ou discriminação à condição de mulher. O crime de homicídio contra a mulher fora destas situações não configurará o feminicídio, tornando-o objetivamente compreensível, inclusive em atendimento ao princípio

\footnotetext{
6 Segundo a Convenção Interamericana para Prevenir, Punir e Erradicar a Violência contra a Mulher - a Convenção de Belém do Pará, assinada na 34ª Sessão da Assembleia Geral da Organização dos Estados Americanos (OEA), de 6 de setembro de 1994, o Brasil se obrigou a "incorporar na sua legislação interna normas penais, civis, administrativas e de outra natureza, que sejam necessárias para prevenir, punir e erradicar a violência contra a mulher, bem como adotar as medidas administrativas adequadas que forem aplicáveis" (art. 7, letra " $\mathrm{C}$ "). Em se tratando de matéria penal, a primeira norma relevante (chamada de primeira geração) foi introduzida pela Lei 10.455, de 13/05/2002, que introduziu na redação ao art. 69, parágrafo único, da Lei dos Juizados Especiais Cíveis e Criminais (Lei n 9.099, de 1995), ao determinar que "Em caso de violência doméstica, o juiz poderá determinar, como medida de cautela, seu afastamento do lar, domicílio ou local de convivência com a vítima." Esta norma seguiu a importantes modificações em diversas normas do Código Penal, introduzidas pela Lei 11.106, de 2005, "retirando da legislação expressões que remetiam à honra da mulher" e determinando a "revogação da causa de extinção da punibilidade referente ao casamento da vítima nos crimes sexuais." (SCARANCE FERNANDES, 2015, p. 15). A norma de "segunda geração" foi a promulgação da Lei Maria da Penha (Lei 11.340, de 2006), que, até hoje, serve como um microssistema de proteção à mulher vítima de violência doméstica. A norma de terceira geração é justamente a Lei 13.104, de 9 de março de 2015, que criou o crime de feminicídio.

7 Projeto de Lei $n^{\circ} 8305$, de 2014.
} 
da legalidade ou da reserva legal, em Direito Penal ${ }^{8}$.

O agressor pode ser o marido, companheiro, parente, amigo, conhecido, ou namorado da mulher ${ }^{9}$, contanto que seja integrante da unidade doméstica, com ou sem vínculo familiar. No âmbito familiar, as pessoas podem ser ou podem se considerar aparentados, unidos por laços naturais, por afinidade ou por vontade expressa; ou que tenham ou tivessem tido relação íntima com a mulher, independentemente de coabitação. ${ }^{10}$ De outra forma, o indivíduo desconhecido da mulher, que realiza homicídio por misoginia, comete crime de feminicídio. Nada impediria que uma mulher fosse autora de crime de feminicídio, desde que do fato se extraia situação de violência doméstica contra a mulher ou misoginia.

A Lei Maria da Penha (Lei $n^{\circ} 11.340$, de 2006) estabeleceu que as relações pessoais de violência contra a mulher independem de orientação sexual. ${ }^{11}$ Como bem definiu o Superior Tribunal de Justiça (REsp 1183378/RS), "as famílias constituídas por pares homoafetivos possuem os mesmos núcleos axiológicos daquelas constituídas por casais heteroafetivos, quais sejam, a dignidade das pessoas de seus membros e o afeto". Portanto, nada impediria que uma mulher, numa relação homoafetiva, pudesse responder por crime de feminicídio.

Por sua vez, a vítima de feminicídio deve ser mulher, inclusive em relação homoafetiva. A divergência pode ocorrer quando a vítima é "homossexual masculino", em especial, quando se trata de transexual, que não se reconhecem no seu sexo biológico e assumem inteiramente o estado psicológico feminino. Existe uma tendência

\footnotetext{
8 O subprincípio da legalidade ou da reserva legal exige que os tipos penais estejam bem definidos, de forma suficientemente clara, em atendimento ao princípio nullum crimen nulla poena sine lege certa. Por este mesmo motivo, fez-se necessário um parágrafo específico (\$2 $2^{\circ}$ A, do art. 121, do CP) para explicar e definir melhor o que é a expressão "em razão da condição de sexo feminino. O feminicídio é a única qualificadora de crime de homicídio que possui um parágrafo próprio.

9 O Superior Tribunal de Justiça o namoro como uma relação íntima de afeto que independe de coabitação, portanto, aplicável a Lei Maria da Penha (REsp 1416580/RJ, Rel. Ministra LAURITA VAZ, QUINTA TURMA, julgado em 01/04/2014, DJe 15/04/2014) e, consectariamente, a lei que prevê o feminicídio.

10 Art. $5^{\circ}$, da Lei Maria da Penha (Lei n 11.340 , de 2006)

11 Art. $5^{\circ}$, parágrafo único: "As relações pessoais enunciadas neste artigo independem de orientação sexual."
} 
de se adotar um critério jurídico, ou seja, somente pode ser considerado mulher quem assim comprova esta condição na certidão de nascimento. ${ }^{12}$ Ocorre que caso haja situações em que seja impossível deixar de reconhecer que a vítima transsexual ou transgênero tenha assumido, de fato, atitude psicológica e aparência femininas, de modo que o sexo masculino registrado em cartório não passe de um fato pouco relevante, o juiz teria que reconhecer a vítima transsexual como mulher, ainda que tenha nascido no corpo masculino, para fins de aplicação do feminicídio? Não há uma resposta fácil, pois o que define mulher não é apenas o órgão feminino (sexo biológico), mas, sobretudo, o papel que o indivíduo desempenha nas relações de gênero.

O homicídio contra mulheres, em geral, possui características próprias, quando é relacionado à violência doméstica e familiar e à violência sexual. O crime cometido em razão do gênero feminino se destaca pelos motivos e pelos modos de execução.

Em geral, os autores deste tipo de delito preferem mutilar e desconfigurar suas vítimas, lesionando o rosto, os seios e os órgãos sexuais. Os agressores preferem o emprego de meios cruéis ou degradantes, visando aumentar, de forma desnecessária, o sofrimento das vítimas. Segundo dados coletados por Waiselfisz (2015), enquanto que, em homicídios praticados contra homens, prepondera o uso de arma de fogo (73,21\% dos casos), nos feminicídios, essa incidência é bem menor (48,8\% dos casos), pois há "concomitante aumento de estrangulamento/sufocação, cortante/penetrante e objeto contundente, indicando maior presença de crimes de ódio ou por motivos fúteis/banais." (WAISELFISZ, 2015, p. 41).

De fato, os agressores possuem uma preferência por meios que causem profundo sofrimento à vítima, como é o caso de: pedradas,

12 Greco (2017, p. 41-44) e Bitencourt (2017, p. 99-100) defendem que o critério jurídico deve ser o adotado. Por sua vez, a COPEVID editou o Enunciado n 30 (001/2016): "A Lei Maria da Penha pode ser aplicada a mulheres transexuais e/ou travestis, independentemente de cirurgia de transgenitalização, alteração do nome ou sexo no documento civil." (Aprovado na I Reunião Ordinária do GNDH em 05/05/2016 e pelo Colegiado do CNPG em 15/06/2016). Assim, a questão ainda é polêmica. 
uso de fogo ${ }^{13}$, pauladas ${ }^{14}$, agressões contundentes em que o agente bate a cabeça da vítima por diversas vezes contra muro ${ }^{15}$, facadas em número excessivo ${ }^{16}$, emprego de veneno ${ }^{17}$, agressões em que o agente esgana e obriga a vítima a ingerir veneno e água sanitária. ${ }^{18}$

Os argumentos de que há diferença entre femicídio e feminicídio e de que o legislador deveria ter mantido a expressão "por razões de gênero feminino não convencem". O femicídio é o homicídio de mulher, enquanto que o feminicídio é o homicídio de mulher por razões de gênero. Na prática, como a maior parte dos homicídios de mulheres envolvem violência doméstica e familiar, menosprezo ou discriminação ao sexo feminino (misoginia), os termos femicídio e feminicídio são empregados de forma indistinta ou intercambiante.

Foi intenção do Projeto de Lei do Senado n 292, de 2013 definir o feminicídio como circunstância objetiva, em razão da situação e da condição pessoal da vítima. Como orienta Vasconcelos (2006, p. 50), "O que se tentará encontrar, na busca da natureza da norma

\footnotetext{
13 "Caso em que o paciente é acusado e foi pronunciado pela prática de homicídio triplamente qualificado praticado contra sua vizinha que contava com 17 anos, levando-a em seu veículo até um local ermo, oportunidade em que arrastou a ofendida até uma gruta, onde passou a perpetrar agressões físicas brutais contra o rosto dela, causando-lhe diversas lesões e fraturas cranianas, ensejadoras de intenso sofrimento e morte, após o que, encharcou o corpo da vítima com um galão de gasolina que trazia no carro e ateou fogo, carbonizando e quase destruindo o cadáver, tudo, ao que parece, motivado pela insatisfação com o fato da vítima não ter acolhido suas investidas amorosas" (STJ, HC 342.660/MG, Rel. Ministro JORGE MUSSI, QUINTA TURMA, julgado em 21/06/2016, DJe 28/06/2016)

14 "Hipótese em que a segregação provisória está fundamentada na necessidade de garantia da ordem pública, em razão da gravidade concreta do delito, evidenciada pelo modus operandi empregado pelo agente na prática da conduta criminosa, uma vez que solicitou o retorno da vítima para sua cidade sob a justificativa de que queria ver seu filho e teria lhe aplicado pauladas na cabeça, demonstrando frieza e crueldade." (STJ, RHC 52.480/MG, Rel. Ministro GURGEL DE FARIA, QUINTA TURMA, julgado em 24/02/2015, DJe 03/03/2015)

15 "Na hipótese, o recorrente bateu a cabeça de sua companheira, por diversas vezes, contra um muro, causando-lhe traumatismo craniano e deixando-a à própria sorte, evadindo-se do local dos fatos. 3. O juiz de primeiro grau demonstrou a necessidade da prisão preventiva para garantir a ordem pública, ante a evidenciada periculosidade do recorrente, pelo modo com que teria perpetrado grave delito contra a vida." (STJ, RHC 50.304/SC, Rel. Ministro ROGERIO SCHIETTI CRUZ, SEXTA TURMA, julgado em 10/02/2015, DJe 23/02/2015)

16 "No presente caso, a prisão cautelar foi decretada em razão da periculosidade do recorrente, revelada pelo modo como o crime foi praticado - por motivo torpe, o acusado desferiu o número excessivo de 22 (vinte e duas) facadas contra a própria amante -, razão suficiente para manter a medida constritiva da liberdade para a garantia da ordem pública." (STJ, RHC 42.370/MG, Rel. Ministro WALTER DE ALMEIDA GUILHERME (DESEMBARGADOR CONVOCADO DO TJ/SP), QUINTA TURMA, julgado em 14/10/2014, DJe 24/10/2014)

17 RHC 49.204/ES, Rel. Ministro JORGE MUSSI, QUINTA TURMA, julgado em 16/09/2014, DJe 25/09/2014

18 RHC 81.317/RS, Rel. Ministro REYNALDO SOARES DA FONSECA, QUINTA TURMA, julgado em 21/03/2017, DJe 29/03/2017.
} 
jurídica, é precisamente a nota que responde por sua existência". O projeto de lei que criou o feminicídio é fruto da Comissão Parlamentar Mista de Inquérito do Congresso Nacional sobre a Violência contra a Mulher no Brasil (CPMIVCM) realizado em 2012. O novo tipo penal teve como objetivo assegurar que o homicídio praticado contra a mulher por razões de gênero fosse considerado crime de Estado. O Projeto visou combater as interpretações jurídicas anacrônicas, tais como as que reconhecem a violência contra a mulher como crime passional. Apesar deste esforço, a redação final do crime de feminicídio não deixa inteiramente clara a natureza objetiva que buscou estabelecer. Assim, faz-se necessárias considerações aprofundadas sobre o assunto.

Apesar de algumas divergências, fruto de uma compreensão apressada e confusa acerca do assunto ${ }^{19}$, os melhores argumentos indicam que o feminicídio é circunstância de natureza objetiva. Nucci (2017), um dos juristas mais influentes, entende que o feminicídio é qualificadora de natureza objetiva. Para ele o feminicídio:

(...) se liga ao gênero da vítima: ser mulher (...) o agente não mata a mulher por ela é mulher, mas o faz por ódio raiva, ciúme, disputa familiar, por sadismo, enfim, motivos variados, que podem ser torpes ou fúteis, podem inclusive ser moralmente relevante. (NUCCI, 2017, p. 768).

Em outros termos, o feminicídio é circunstância que vai além dos motivos do crime. Isto somente é possível se o feminicídio for definido e encarado como circunstância de natureza objetiva, a fim de evitar confusão conceitual. De fato, o feminicídio se destaca como qualificadora própria, que não pode ser confundida com as demais

19 Cunha e Pinto (2015, p. 483) e Capez (2017, p. 89) entendem que feminicídio é circunstância de natureza subjetiva. Contudo, sem aprofundamento, como se ver no presente trabalho, feminicídio não se confunde com motivo. 
circunstâncias qualificadoras: os motivos (torpe ${ }^{20}$ ou fútil ${ }^{21}$ ), os meios (emprego de veneno, fogo, explosivo, asfixia, tortura ou outro meio insidioso ou cruel, ou de que possa resultar em perigo comum), os modos (à traição, de emboscada, ou mediante dissimulação ou outro recurso que dificulte ou torne impossível a defesa da vítima), e os fins (para assegurar a execução, a ocultação, a impunidade ou vantagem de outro crime) ${ }^{22}$. Não haveria sentido em se criar uma circunstância que qualificasse o homicídio como crime hediondo, se sua definição legal já pudesse ser extraída de outra circunstância qualificadora. Interpretação em sentido contrário demandaria muitas dificuldades, pois a violência doméstica e familiar contra a mulher já constava como circunstância agravante no Código Penal ${ }^{23}$, portanto, o feminicídio teve como efeito prático transformar um crime de natureza simples em qualificado, reforçando o combate a violência contra mulher.

O feminicídio é mais familiar ao sistema de proteção previsto na Lei Maria da Penha (Lei $n^{\circ} 11.340$, de 2006), que criou mecanismos para coibir a violência doméstica e familiar contra a mulher. Assim, faz-se necessário o aprofundamento de seu conceito e de sua natureza jurídica, como se dará a seguir.

\footnotetext{
20 Torpe, motivo que qualifica o crime de homicídio (art. 121, $\S 2^{\circ}$, inciso I, do CP), significa procedimento ignóbil, vergonhoso, repugnante sórdido, crime praticado por sujeitos não capacitados a viver uma sociedade harmônica. FEU ROSA define como motivo torpe "aquele que se contrapõe ostensivamente às mínimas regras éticas e morais da sociedade, que afronte os bons costumes, que imprime ao crime, além do aspecto reprovável normal, o caráter de baixeza e indignidade" (1995, pág. 74). Para DAMÁSIO DE JESUS "motivo torpe é o moralmente reprovável, demonstrativo de depravação espiritual do sujeito. Torpe é o motivo abjeto, desprezível." (1998, pag. 67). Para NUCCI, "torpe é atributo do que é repugnante, indecente, ignóbil, logo, provocador de excessiva repulsa na sociedade". (2015, pág. 617).

21 Motivo fútil, sinônimo de banal, insignificante, frívolo, sem importância, sem valor. Para Hungria (1953, p. 159), fútil é o motivo que, "pela sua mínima importância, não é causa suficiente para o crime. Ele traduz o egoísmo intolerante, prepotente, mesquinho, que vai até a insensibilidade moral" Nucci (2015, pág. 617) ensina que fútil "[...] significa que a causa fomentadora da eliminação da vida alheia calcou-se em elemento insignificante se comparado ao resultado provocado [...] é a flagrante desproporção entre o motivo e o resultado obtido".

22 Podem ser definidas como circunstâncias de natureza subjetiva as qualificadoras previstas nos incisos I, II e V do $\$ 2^{\circ}$, do art. 121 , do CP (motivos e fins). Por sua vez, as qualificadoras de natureza objetiva são aquelas previstas nos incisos III e IV e VII do $\S 2^{\circ}$, do art. 121 , do CP (meios, modos e praticado contra agentes de segurança).

23 Art. 61, inciso II, letra $f$, do CP: "ter o agente cometido o crime com abuso de autoridade ou prevalecendo-se de relações domésticas, de coabitação ou de hospitalidade, ou com violência contra a mulher na forma da lei específica."
} 


\section{CONCEITO E NATUREZA JURÍDICA DO FEMINICÍDIO}

O feminicídio resulta da ideologia de que o machismo e o poder se sobressaem como instrumentos de dominação e de subjugação. Trata-se de um crime de ódio, semelhante ao racismo e ao genocídio, crimes que se dirigem a categorias com método despersonalizado. Como ensina Eluf (2014):

Em uma primeira análise, superficial e equivocada, poderia parecer que a paixão, decorrente do amor, tornaria nobre a conduta do homicida, que teria matado por não suportar a perda de seu objeto de desejo ou para lavar sua honra ultrajada. No entanto, a paixão que move a conduta criminosa não resulta do amor, mas sim do ódio, da possessividade, do ciúme ignóbil, da busca da vingança, do sentimento de frustração aliado à prepotência, da mistura de desejo sexual frustrado com rancor. (ELUF, 2014, p. 157).

O homicídio pode ser motivado por impotência, ciúme, egocentrismo, possessividade, prepotência e até vaidade ${ }^{24}$, mas somente é feminicídio se é praticado em razão do gênero feminino. São motivos comuns para o feminicídio o término de relacionamento ${ }^{25}$ (ou negativa em reatar o relacionamento $\left.{ }^{26}\right)$, a rejeição amorosa ${ }^{27}$ ou conjugal ${ }^{28}$, discussão em meio a bebidas alcoólicas ${ }^{29}$, adultério ${ }^{30}$, etc. Certo que o feminicista não mata por amor, contudo, raramente o crime de homicídio não é um crime de ódio. Assim, a nota que diferencia o homicídio do feminicídio é justamente o que define este último: crime

24 Segundo Fernandes (2015, p. 69), o "perfil do homem que pratica feminicídio é de alguém autocentrado, egoísta e muita vezes com baixa autoestima. Mata não por amor, mas por um sentimento de posse e por sua reputação."

25 STJ, HC 344.969/SP, Rel. Ministro JORGE MUSSI, QUINTA TURMA, julgado em 23/02/2016, DJe $07 / 03 / 2016$

26 STJ, HC 342.660/MG, Rel. Ministro JORGE MUSSI, QUINTA TURMA, julgado em 21/06/2016, DJe $28 / 06 / 2016$

27 STJ, HC 303.542/MG, Rel. Ministro RIBEIRO DANTAS, QUINTA TURMA, julgado em 15/09/2016, DJe $21 / 09 / 2016$

28 STJ, RHC 41.071/RS, Rel. Ministro JORGE MUSSI, QUINTA TURMA, julgado em 17/12/2013, DJe 05/02/2014

29 STJ, RHC 75.775/RO, Rel. Ministro ROGERIO SCHIETTI CRUZ, SEXTA TURMA, julgado em 04/10/2016, DJe 04/11/2016

30 STJ, REsp 203.632/MS, Rel. Ministro FONTES DE ALENCAR, SEXTA TURMA, julgado em 19/04/2001, DJ 19/12/2002, p. 454 
praticado contra a mulher, em razão de uma violência que possui caráter institucional, em que há uma "relação assimétrica de poder, com dominação do homem e submissão da mulher (...) violência, em razão do gênero, é exercida simplesmente porque o agressor é homem e a vítima é mulher." (FERNANDES, 2015, p. 239).

Com muito humor e sabedoria, Veríssimo (2015, p. 10-11) sentenciou que o "Homem não tem ciúmes por amar. Ciúmes não é uma questão entre o homem e a pessoa que ama. Ou é, mas a pessoa que ele ama é ele mesmo. Ciúmes é sempre entre o homem e ele mesmo." ${ }^{\prime 31}$ O ciúme é um sentimento humano, portanto, pode ser nobre ou cruel.

Quando o homem mata a mulher por ciúmes, o faz por motivos que podem ser fúteis ou torpes, ou que podem ter resultado de uma injusta provocação da vítima, que por sua vez, podem ou não constituir homicídio privilegiado ${ }^{32}$ ou atenuante de violenta emoção. ${ }^{33}$ Podem constituir tão somente um injusto penal, sem causas de aumento ou diminuição de pena. ${ }^{34} \mathrm{O}$ mesmo se aplicaria se o crime de

\footnotetext{
31 O feminicista normalmente alega questões de honra para justificar seu delito contra a mulher, como se a honra pudesse ser restituída com o sangue e a vida da vítima. Contudo, o crime de honra é uma falácia, um mito processual, que visa justificar o injustificável. Não há como recuperar honra, eis que o crime já é desonra. Fernandes (2016, p. 276), com seu humor peculiar, ao comentar sobre honra ferida, contou o que um homem desonrado disse: "Declarou com toda a dignidade: 'Admito perder tudo, menos a honra!' E continuou procurando."

32 Art. $121, \S 1^{\circ}$, do CP. O homicídio privilegiado ocorre quando o agente comete o crime impelido por motivo de relevante valor social ou moral, ou sob o domínio de violenta emoção, logo em seguida a injusta provocação da vítima. Na magistral lição de Feu Rosa (1995, p. 66), "o homicídio privilegiado requer a existência de um fato qualquer capaz de comover o indivíduo normal, tornando-o exaltado e fazendo-o perder os freios inibitórios. O agente fica possuído por estado emocional incontrolável, que o conduz ao crime". Mirabete (1999, p. 648) adverte que "não caracteriza a causa de redução da pena no chamado homicídio passional, e ela só ocorrerá se preencher os requisitos apontados para o homicídio emocional. A morte causada por ciúme ou vingança por abandono da pessoa amada não constitui, por si isso, homicídio privilegiado." O homicídio privilegiado é enquadrado como crime de natureza subjetiva, portanto, incompatível com o homicídio qualificado de natureza subjetiva e, contrario sensu, é compatível com o homicídio qualificado de natureza objetiva, entre os quais, o feminicídio. Esta é a orientação do Supremo Tribunal Federal (HC 98265, DJe 13/05/2010) e do Superior Tribunal de Justiça (HC 199.602, DJe 24/03/2014, HC 171.652, DJe 23/10/2012 e HC 346.132/ SP, DJe 01/04/2016).

33 art. 65 , inciso III, $C$, do CP

34 Antigamente imperava na jurisprudência brasileira o dogmatismo jurídico do tipo: "TJSP: 'Nos casos em que o ciúme é mencionado como circunstância qualificadora, sempre é enquadrado como motivo fútil e não torpe' (RT 691/310)" (MIRABETE, 1999 p. 655). A jurisprudência mais recente do Superior Tribunal de Justiça entende que: "O sentimento de ciúme pode tanto inserir-se na qualificadora do inciso I ou II do $\S 2^{\circ}$, ou mesmo no privilégio do $\S 1^{\circ}$, ambos do art. 121 do $\mathrm{CP}$, análise feita concretamente, caso a caso." (AgRg no REsp 1457054/PR, Rel. Ministro REYNALDO SOARES DA FONSECA, QUINTA TURMA, julgado em 21/06/2016, DJe 29/06/2016). É bem verdade que o STJ já decidiu que "O ciúme, por si só, sem outras circunstâncias, não caracteriza o motivo torpe.", mas pode sê-lo em razão das peculiaridades do caso, do "despropósito da ação praticada bem como a
} 
homicídio fosse praticado por um homem contra outro homem, de modo que é fácil concluir que o feminicídio pode ser motivado por ciúmes, mas não sofre alteração em razão da natureza dos ciúmes. Os ciúmes que um homem sente por outro não possui o mesmo significado, status familiar ou social que os ciúmes que um homem sente por uma mulher, portanto, estas duas situações não podem ser tratadas da mesma forma.

Os ciúmes, sentimento tão natural entre casais, pode ser até desejável, mas quando é utilizado para motivar um crime contra a mulher, raramente, deixa de ser censurável, podendo ser até torpe ou fútil, a depender de sua origem. De qualquer modo, a violência não combina com o amor, e não pode significar defesa da honra, pois o crime, por si só, já é desonra. Como bem definiu Lyra (1975):

O verdadeiro passional não mata. O amor é, por natureza e por finalidade, criador, fecundo, solidário, generoso. Ele é cliente das pretorias, das maternidades, dos lares e não dos necrotérios, dos cemitérios, dos manicômios. O amor, o amor mesmo, jamais desceu ao banco dos réus. Para os fins de responsabilidade, a lei considera apenas o momento do crime. E nele o que atua é o ódio. O amor não figura nas cifras da mortalidade e sim nas da natalidade; não tira, põe gente no mundo. Está nos berços e não nos túmulos (LYRA, 1975, p. 97).

O crime passional em que foi autor um homem e vítima outro homem pode significar uma disputa irracional, mas quando a vítima é mulher, já se busca saber se o homem teve motivo "justo" para fazê-lo. Em verdade, o crime passional é um mito penal que visa a suavização ou a inibição da responsabilidade criminal do agressor. Como ensina Casara (2015, p. 86), o "mito penal pode ser conceituado como o elemento do discurso que versa sobre o poder penal (ou seja, sobre o poder de atribuir respostas estatais às condutas etiquetadas

sua crueldade aviltante." (HC 123.918/MG, Rel. Ministro FELIX FISCHER, QUINTA TURMA, julgado em 13/08/2009, DJe 05/10/2009). O ciúme pode ser torpe quando praticado por vingança e egoísmo (HC 145.399/MG, Rel. Ministro HAROLDO RODRIGUES (DESEMBARGADOR CONVOCADO DO TJ/CE), SEXTA TURMA, julgado em 16/09/2010, DJe 25/10/2010). 
de delitos [...]". Na tensão entre o poder penal e o jus libertatis, o crime passional funcionaria como instrumento útil ao estado de liberdade, pois tenciona para justificar o delito como ato de amor desequilibrado ou de sofrimento inescrutável, algo entre a inexibilidade de conduta diversa e a inimputabilidade penal. Enfim, um ato de paixão sem freios inibitórios. Trata-se de categoria mitológica que visa vivificar o ato criminoso como algo mais próximo de nobreza virtuosa ou de um infortúnio indesejável.

Não existem dificuldades de entender o feminicídio quando decorre de violência doméstica e familiar contra mulher, ou de feminicídio íntimo ${ }^{35}$ Dificuldades podem aparecer quando se tratar de feminicídio não íntimo, no qual o agressor não conhece a vítima, contudo a mata pelo fato de ser mulher (como seria o caso do estupro, seguido de homicídio). Trata-se do feminicídio por menosprezo ou discriminação à condição de mulher. A COPEVID ${ }^{36}$ entende a misoginia como circunstância de natureza objetiva, em face da situação e da condição pessoal da vítima. Em reunião realizada em 22/09/2015, foi aprovado o seguinte enunciado:

Enunciado n $^{\circ} 24(006 / 2015)$ : A qualificadora do feminicídio,
na hipótese do art. 121, §2-A, inciso II, do Código Penal,
possui natureza objetiva, em razão da situação de desigual-
dade histórico-cultural de poder, construída e naturalizada
como padrão de menosprezo ou discriminação à mulher.
(Aprovado na II Reunião Ordinária do GNDH e pelo CNPG
em 22/09/2015). (ENUNCIADOS..., 2017).

A situação de desigualdade histórico-cultural de poder entre homens e mulheres possui caráter objetivo. O ódio, o desprezo ou a repulsa contra a mulher, constituem violência institucionalizada. É, nitidamente, situação e condição pessoal da mulher vítima de violência. Isto merece uma reflexão sincera e autêntica. Não há dúvida

$35 \mathrm{O}$ art. $7^{\circ}$ da Lei $\mathrm{n}^{\circ} 11.340$ define as formas de violência: física, psicológica, sexual, patrimonial e moral. A agressão física mais grave é a morte da mulher.

36 Comissão Permanente de Combate à Violência Doméstica e Familiar contra a Mulher - COPEVID, vinculada ao Grupo Nacional de Direito Humanos do Conselho Nacional de Procuradores-Gerais dos Ministérios Públicos dos Estados e da União 
de que a igualdade entre homens e mulheres, estabelecida pelo art. $5^{\circ}$, inciso I, da Constituição Federal ("homens e mulheres são iguais em direitos e obrigações") não consegue refratar a realidade. A igualdade é desejável, contudo é irrealizável dentro de parâmetros ideais e universais.

É incontestável que há uma profunda desigualdade de oportunidades nos campos do emprego, da renda e da política. As mulheres sempre estão em desvantagens em relação aos homens. A construção do conceito de violência de gênero pressupõe uma análise de natureza objetiva, eis que acompanha a própria formação dos seres humanos e de suas gerações. As relações de poder entre homens e mulheres são necessariamente construções psicossociais. A formação do homem, em síntese, é de negação reiterada: "não sou uma menina, não sou minha mãe, enfim, não sou uma mulher". Assim, o homem cria uma imagem da própria identidade como pessoa que não é uma mulher. A negação do gênero feminino traz, como consequência, a violência de gênero como construção social.

No contexto da construção da identidade de gênero é difícil sustentar que a misoginia se trata de motivo determinante, quando a construção dos significados e dos sentidos vai além do desejo próprio do indivíduo.

O desafio, assim, é rechaçar o suposto caráter subjetivo do feminicídio. É preciso repelir a ideia que a misoginia é um valor social e moral de natureza pessoal. É preciso fazer com que os operadores do Direito e os jurados do Tribunal do Júri compreendam que as razões de gênero não são particulares, mas assumidas de maneira individual pelo agressor em um contexto de violência estrutural e institucionalizada.

Por estas razões de caráter institucional, não é possível mais afirmar que o feminicídio seja de natureza subjetiva. Ainda é preciso colocar alguma luz sobre este assunto.

O Código Penal brasileiro foi diretamente inspirado pelo Código 
Penal italiano (Codice penale, Decreto-Lei no 1398, promulgado em 19/10/1930), que define como de natureza objetiva as "condições ou qualidades pessoais do ofendido." ${ }^{\prime 37}$ Do mesmo modo, Fragoso (1987, p. 343) e Jesus (1998, p. 59) entendem como de natureza objetiva "a situação ou a condição pessoal da vítima"38 e a "qualidade da vítima"39. Assim, não se trata de nenhuma novidade. O que ocorreu logo após a publicação da lei que criou o feminicídio, foi um equívoco doutrinário (que ainda persiste) ao confundir feminicídio com motivo torpe ou fútil. Sabe-se porém, como visto, que feminicídio pode ocorrer sem que o homicídio tem sido motivado por torpeza ou futilidade, ou seja, o motivo não é móvel da violência de gênero, pois esta é de natureza objetiva, institucional e cultural. ${ }^{40}$

\begin{abstract}
$37 \mathrm{O}$ art. 70, do Código Penal italiano descreve as circunstâncias objetivas e subjetivas nos seguintes moldes: "[...] para os efeitos da lei penal: 1) são circunstâncias objetivas as que concernem à natureza, à espécie, aos meios, ao objeto, ao tempo, ao lugar e a qualquer outra modalidade de ação, à gravidade do dano ou do perigo, ou às condições ou qualidades pessoais do ofendido; 2) são circunstâncias subjetivas as que concernem à intensidade do dolo ou do grau da culpa, ou às condições e qualidades do culpado, ou às relações entre o culpado e o ofendido, ou àquelas inerentes à pessoa do culpado" (BETTIOL, 2000, p. 448)

38 "As circunstâncias classificam-se em subjetivas e objetivas. As circunstâncias subjetivas ou pessoais são as que se referem aos motivos determinantes, à qualidade ou condição pessoal do agente, às suas relações com a vítima ou com os demais co-autores ou partícipes. As circunstâncias objetivas relacionam-se com os meios e modos de execução, o tempo, o lugar e a ocasião, a situação ou a condição pessoal da vítima e o objeto material do crime. Essa distinção entre circunstâncias subjetivas e objetivas é fundamental. Só as primeiras se comunicam aos partícipes (art. 30, CP)" (FRAGOSO, 1987, p. 343).

39 "Circunstâncias objetivas são as que se relacionam com os meios e modos de realização do crime, tempo, ocasião, lugar, objeto material e qualidade da vítima. Circunstâncias subjetivas (de caráter pessoal) são as que só dizem respeito à pessoa do participante, sem qualquer relação com a materialidade do delito, com os motivos determinantes, suas condições ou qualidades pessoais e relações com a vítima ou com outros concorrentes." (DAMÁSIO DE JESUS, 1998, p. 59)

40 Neste tocante, ressalte-se a decisão do Tribunal de Justiça do Distrito Federal e dos Territórios, que reconheceu a natureza objetiva do feminicídio: "1 Réu pronunciado por infringir o artigo 121 , $\S 2^{\circ}$, inciso I, do Código Penal, depois de matar a companheira a facadas motivado pelo sentimento egoístico de posse. 2 Os protagonistas da tragédia familiar conviveram sob o mesmo teto, em união estável, mas o varão nutria sentimento egoístico de posse e, impelido por essa torpe motivação, não queria que ela trabalhasse num local frequentado por homens. A inclusão da qualificadora agora prevista no artigo $121, \S 2^{\circ}$, inciso VI, do Código Penal, não poderá servir apenas como substitutivo das qualificadoras de motivo torpe ou fútil, que são de natureza subjetiva, sob pena de menosprezar o esforço do legislador. A Lei 13.104/2015 veio a lume na esteira da doutrina inspiradora da Lei Maria da Penha, buscando conferir maior proteção à mulher brasileira, vítima de condições culturais atávicas que lhe impuseram a subserviência ao homem. Resgatar a dignidade perdida ao longo da história da dominação masculina foi a ratio essendi da nova lei, e o seu sentido teleológico estaria perdido se fosse simplesmente substituída a torpeza pelo feminicídio. Ambas as qualificadoras podem coexistir perfeitamente, porque é diversa a natureza de cada uma: a torpeza continua ligada umbilicalmente à motivação da ação homicida, e o feminicídio ocorrerá toda vez que, objetivamente, haja uma agressão à mulher proveniente de convivência doméstica familiar. (TJDFT. Acórdão n.904781, 20150310069727RSE, Relator: GEORGE LOPES LEITE, $1^{\text {a }}$ Turma Criminal, Data de Julgamento: 29/10/2015, Publicado no DJE: 11/11/2015. Pág.: 105). Da mesma forma, o Superior Tribunal de Justiça, em decisão monocrática da Ministra MARIA THEREZA DE ASSIS MOURA, reconheceu a natureza objetiva do feminicídio (RECURSO ESPECIAL No 1.629.152 - DF (2016/0256850-3), Ministra MARIA THEREZA DE ASSIS MOURA, 03/02/2017).
\end{abstract}


A violência doméstica e familiar contra a mulher e a misoginia decorrem de relações de poder desiguais entre os sexos, em que o feminino é o gênero em estado de vulnerabilidade. Assim, o feminicídio é circunstância sempre de natureza objetiva.

O feminicídio foi criado em face das estatísticas que indicam um recrudescimento de homicídio de mulheres nas últimas décadas. A taxa de 4,8 homicídios por 100 mil mulheres coloca o Brasil na incômoda $5^{\text {a }}$ posição entre os países que mais matam mulheres, conforme dados da Organização Mundial da Saúde (OMS) (WAISELFISZ, 2015, p. 29) ${ }^{41}$. O Brasil somente não supera El Salvador, Colômbia, Guatemala e Federação Russa. Contudo, a taxa brasileira é 48 vezes maior do que a do Reino Unido, por exemplo. Waiselfisz (2015, p. 29) afirmou que "Esse é um claro indicador que os índices do País são excessivamente elevados." Segundo a pesquisa, em 1980, ocorreram 1.353 homicídios femininos com taxa de 2,3 casos para cada 100 mil mulheres. Já em 2013, foram contabilizados 4.762 homicídios femininos, com taxa de 4,8 casos para cada 100 mil mulheres, ou seja, 13 homicídios femininos diários. Assim, comprova-se um aumento significativo de homicídios femininos. Conforme explica Waiselfisz (2015):

Pelos registros do SIM $^{42}$, entre 1980 e 2013, num ritmo crescente ao longo do tempo, tanto em número quanto em taxas, morreu um total de 106.093 mulheres, vítimas de homicídio. Efetivamente, o número de vítimas passou de 1.353 mulheres em 1980, para 4.762 em 2013, um aumento de 252\%. A taxa, que em 1980 era de 2,3 vítimas por 100 mil, passa para 4,8 em 2013, um aumento de $111,1 \%$ (WAISELFISZ, 2015, p. 11).

Ainda segundo dados coletados por Waiselfisz (2015, p. 50), 71,9\% dos casos de violência contra as mulheres ocorrem eminentemente na esfera doméstica, ou seja, na residência da vítima. Para as jovens

41 A pesquisa desenvolvida pelo sociólogo Julio Jacobo Waiselfisz considerou 83 (oitenta e três) países com dados homogêneos.

42 Sistema de Informações sobre Mortalidade. 
e adultas de 18 aos 59 anos, o principal agressor é parceiro ou ex-parceiro da mulher. Parentes imediatos, parceiros ou ex-parceiros corresponderam à $67,2 \%$ dos casos de autoria de violência contra a mulher.

Segundo pesquisa do Instituto de Pesquisa Econômica Aplicada (IPEA), ocorre 1 feminicídio a cada uma hora e meia ou são registrados 5.664 assassinatos de mulheres por ano. (FERNANDES, 2015, p. 79)

Conforme pesquisa realizada pelo Data Popular e pelo Instituto Patrícia Galvão (PERCEPÇÃO..., 2013, p. 34-50, a sobre percepção do público sobre violência e assassinato de mulheres: $70 \%$ dos entrevistados acreditam que a mulher sofre mais violência dentro de casa do que em espaços públicos; 69\% acreditam que a violência contra a mulher não ocorre apenas em famílias pobres; e 85\% concordam que as mulheres que denunciam seus parceiros correm mais riscos de sofrer assassinatos; apenas 17\% concordam com a ideia que "mulher que apanha é porque provoca"; 86\% concordam que "quem ama não bate"; 92\% concordam que quando as agressões contra a esposa/companheira ocorrem com frequência, podem terminar em assassinato; 88\% consideram que os assassinatos de mulheres por parceiros aumentaram nos últimos 5 anos; e 85\% consideram que a Justiça não pune adequadamente os assassinos das parceiras.

As estatísticas alarmantes e a percepção popular indicam que a violência contra mulher deve possui um tratamento jurídico diferenciado por se tratar de crime eivado por violência institucional. Não é a toa que a orientação do Supremo Tribunal Federal é tratar o crime de violência doméstica e familiar contra a mulher como crime de natureza pública e incondicional, do qual não depende da representação da vítima. ${ }^{43} \mathrm{O}$ feminicídio é o último degrau na chamada

43 ADI 4.424, voto do rel. min. Marco Aurélio, julgamento em 9-2-2012, Plenário, DJE de 01/08/2014).
Trecho do voto: "Eis um caso a exigir que se parta do princípio da realidade, do que ocorre no
dia a dia quanto à violência doméstica, mais precisamente a violência praticada contra a mulher.
Os dados estatísticos são alarmantes. Na maioria dos casos em que perpetrada lesão corporal de
natureza leve, a mulher, agredida, a um só tempo, física e moralmente, acaba, talvez ante óptica
assentada na esperança, por afastar a representação formalizada, isso quando munida de coragem
a implementá-la. Conforme ressaltado na inicial, confeccionada com o desejável esmero, dados 
escalada da violência, que precede à ridiculização, ao controle e ao isolamento, à ameaça e à violência física. ${ }^{44} \mathrm{O}$ ciclo da violência e o "silêncio" da vítima podem ser fatores decisivos para a morte. Segundo Fernandes (2015, p. 124), não é incomum que o feminicista não possua registros policiais como agressor doméstico, pois a vítima resiste em registrar boletins de ocorrência contra o agressor. Quando o registro de crime doméstico ocorre, a vítima ainda pode renunciar a representação, se retratar ou inocentar o agressor, impedindo, assim, sua responsabilização criminal. A ausência de registro e a atuação no sentido de obter a absolvição do agressor estimulam a continuidade do ciclo de violência. ${ }^{45}$

estatísticos demonstram que o percentual maior é de renúncia à representação, quer deixando-se de ter a iniciativa, quer afastando-a do cenário jurídico. [...] Iniludivelmente, isso se deve não ao exercício da manifestação livre e espontânea da vítima, mas ao fato de vislumbrar uma possibilidade de evolução do agente, quando, na verdade, o que acontece é a reiteração de procedimento e, pior, de forma mais agressiva ainda em razão da perda dos freios inibitórios e da visão míope de que, tendo havido o recuo na agressão pretérita, o mesmo ocorrerá na subsequente. Os dados estatísticos são assombrosos relativamente à progressão nesse campo, vindo a desaguar, inclusive, em prática que provoque a morte da vítima. Sob o ponto de vista feminino, a ameaça e as agressões físicas não vêm, na maioria dos casos, de fora. Estão em casa, não na rua. Consubstanciam evento decorrente de dinâmicas privadas, o que, evidentemente, não reduz a gravidade do problema, mas a aprofunda, no que acirra a situação de invisibilidade social. Na maior parte dos assassinatos de mulheres, o ato é praticado por homens com quem elas mantiveram ou mantêm relacionamentos amorosos. [...] No tocante à violência doméstica, há de considerar-se a necessidade da intervenção estatal. [...] No caso presente, não bastasse a situação de notória desigualdade considerada a mulher, aspecto suficiente a legitimar o necessário tratamento normativo desigual, tem-se como base para assim se proceder a dignidade da pessoa humana - art. $1^{\circ}$, III -, o direito fundamental de igualdade - art. $5^{\circ}$, I - e a previsão pedagógica segundo a qual a lei punirá qualquer discriminação atentatória dos direitos e liberdades fundamentais - art. $5^{\circ}$, XLI. A legislação ordinária protetiva está em fina sintonia com a Convenção sobre a Eliminação de Todas as Formas de Violência contra a Mulher, no que revela a exigência de os Estados adotarem medidas especiais destinadas a acelerar o processo de construção de um ambiente onde haja real igualdade entre os gêneros. Há também de se ressaltar a harmonia dos preceitos com a Convenção Interamericana para Prevenir, Punir e Erradicar a Violência contra a Mulher - a Convenção de Belém do Pará -, no que mostra ser a violência contra a mulher uma ofensa aos direitos humanos e a consequência de relações de poder historicamente desiguais entre os sexos. [...] Descabe interpretar a Lei Maria da Penha de forma dissociada do Diploma Maior e dos tratados de direitos humanos ratificados pelo Brasil, sendo estes últimos normas de caráter supralegal também aptas a nortear a interpretação da legislação ordinária. Não se pode olvidar, na atualidade, uma consciência constitucional sobre a diferença e sobre a especificação dos sujeitos de direito, o que traz legitimação às discriminações positivas voltadas a atender as peculiaridades de grupos menos favorecidos e a compensar desigualdades de fato, decorrentes da cristalização cultural do preconceito. [...] Procede às inteiras o pedido formulado pelo PGR, buscando-se o empréstimo de concretude maior à CF. Deve-se dar interpretação conforme à Carta da República aos arts. 12, I, 16 e 41 da Lei 11.340/2006 - Lei Maria da Penha - no sentido de não se aplicar a Lei 9.099/1995 aos crimes glosados pela Lei ora discutida, assentando-se que, em se tratando de lesões corporais, mesmo que consideradas de natureza leve, praticadas contra a mulher em âmbito doméstico, atua-se mediante ação penal pública incondicionada. [...]"

44 Scarance Fernandes $(2015$, p. 68) defende que "A violência não interrompida por uma intervenção processual dotada de efetividade pode evoluir para um feminicídio", apesar de não haver como saber se a mulher poderá ser assassinada pelo agressor. Portanto, é muito importante não aceitar nenhuma violência de gênero para que a mulher possua melhor capacidade de reagir e se livrar de uma violência ainda mais grave.

45 O ciclo de violência é composto por três fases: Tensão, Explosão e "Lua de Mel". Na primeira fase, existe uma "clima sobrecarregado, tenso e instável", na qual a mulher sofre humilhação e 
Apesar desta inegável realidade, e da orientação dos tribunais em tratar a violência doméstica e familiar contra a mulher como crime de natureza especializada, existem dificuldades para o eficiente processamento dos delitos. Por exemplo, não são comuns informações sobre o ciclo da violência doméstica nos inquéritos e processos de feminicídio. Em geral, a equipe de atendimento multidisciplinar ou serviço similar está vinculada ao Juizado de Violência Doméstica e Familiar contra a Mulher e não servem a outros setores do Poder Judiciário, em especial, o Tribunal do Júri.

Ante a precariedade da prova sobre o ciclo de violência, existe uma forte tendência de que os homicídios tentados contra mulheres sejam desclassificados para lesões corporais. Afinal, os inquéritos e processos judiciais costumam dar uma especial atenção ao comportamento da vítima. Assim preponderam fatores de recriminação e revitimização. É recorrente o esquecimento da inclusão da qualificadora do feminicídio e até mesmo da agravante do art. 61, inciso II, letra f, do $\mathrm{CP}$, nas denúncias, pronúncias ou sentenças condenatórias. O sistema de justiça é refratário quanto ao reconhecimento do feminicídio. Os crimes são retratados como se fossem situações particulares entre acusados e vítimas e não como um crime de Estado (A VIOLÊNCIA DOMÉSTICA FATAL..., 2015, p. 53-57).

Ante a complexidade do crime de feminicídio, a COPEVID editou o Enunciado nº 34 (005/2016), estabelecendo que:

O Ministério Público deve investir na capacitação de seus membros para o enfrentamento à violência doméstica contra a mulher, utilizando-se como documentos de referência as ‘Diretrizes nacionais de investigação criminal

\footnotetext{
xingamentos, submetendo-se ao descontrole e às vontades do agressor, que coloca a culpa de seu próprio comportamento na mulher, de modo que justifica seu próprio comportamento como uma forma de "corrigir" a mulher. Na segunda fase, o agressor comete os crimes (ameaças, agressões, estupro, etc.), a mulher que é incapaz de reagir, suporta a violência, em graus cada vez mais passivos e depressivos, conforme o ciclo de violência se repete e se estende. Na última fase, o agressor se arrepende, por "medo de ser abandonado ou punido, modifica seu comportamento, chora pede perdão, entrega flores, presentes, promete que nunca mais agirá desse modo, deixa de consumir álcool, procura emprego, enfim, convence a parceira de que a agressão não se repetirá." Contudo, o ciclo se repete, perpetuando os sentimentos de vergonha, crença na mudança do parceiro, inversão de culpa, descrédito na Justiça e medo de reviver os traumas (FERNANDES, 2015, p. 124-127).
} 
com perspectiva de gênero' da COMJIB/EuroSociAL e as 'Diretrizes Nacionais para Investigar, Processar e Julgar com Perspectiva de Gênero as Mortes Violentas de Mulheres Feminicídios' da ONU Mulheres. (Aprovado na I Reunião Ordinária do GNDH em 05/05/2016 e pelo Colegiado do CNPG em 15/06/2016). (ENUNCIADOS..., 2017).

A investigação e o processamento dos crimes de feminicídio depende, sobretudo, de uma mudança de paradigma: o sistema de proteção da mulher vítima de violência doméstica também deve servir para instruir os processos de competência do Tribunal do Júri.

Ademais, os promotores do júri precisam incorporar, desde a fase de investigação, a perspectiva de gênero e procurar instruir os processos como se estivessem atuando perante os Juizados de Violência Doméstica e Familiar contra a Mulher. Para tanto, capacitação e o cumprimento de diretrizes nacionais no processamento dos feminicídios são tão importantes. A adoção de medidas de proteção, assistência e de reparação são ainda mais fundamentais, eis que a vítima sobrevivente pode se retratar ou faltar com a verdade, impossibilitando a punição do agressor.

Não raras vezes, a família da vítima falecida também necessita de assistência e orientação, eis que sua participação na reconstrução dos fatos é essencial para o estabelecimento da verdade processual. Até mesmo deve ser observado o emprego de linguagem não discriminatória e livre de estereótipos de gênero ${ }^{46}$

\footnotetext{
46 Importante destacar que o julgado do STJ que anulou decisão do júri que absolveu acusado de feminicídio porque alegava legítima defesa da honra porque "a vítima não tinha comportamento recatado". O STJ entendeu que não havia requisitos para legítima defesa, a ver: "1. Relata a denúncia haver o marido, incurso nas sanções do art. 121, § $2^{\circ}$, incisos I e IV, do Código Penal, efetuado diversos disparos contra sua mulher, de quem se encontrava separado, residindo ela, há algum tempo (mais de 30 dias), em casa de seus pais, onde foi procurada, ao que parece, em tentativa frustrada de reconciliação, e morta. 2. A absolvição pelo Júri teve por fundamento ação em legítima defesa da honra, decisão confirmada pelo Tribunal de Justiça, ao entendimento não ser aquela causa excludente desnaturada pelo fato de o casal estar separado, há algum tempo, e porque "a vítima não tinha comportamento recatado". 3. Nestas circunstâncias, representa o acórdão violação à letra do art. 25 do Código Penal, no ponto que empresta referendo à tese da legítima defesa da honra, sem embargo de se encontrar o casal separado há mais de trinta dias, com atropelo do requisito relativo à atualidade da agressão por parte da vítima. Entende-se em legítima defesa, reza a lei, quem, usando moderadamente dos meios necessários, repele injusta agressão, atual ou iminente, a direito seu ou de outrem. 4. A questão, para seu deslinde e solução, não reclama investigação probatória, com incidência da súmula 7 do STJ, pois de natureza jurídica." (REsp 203.632/MS, Rel. Ministro FONTES DE ALENCAR, SEXTA TURMA, julgado em 19/04/2001, DJ 19/12/2002, p. 454)
} 
Deve-se combater as teses de defesa que visam desqualificar a vítima ou retratar o agressor como indivíduo benquisto ou apaixonado. Linhas de defesa que visem a reprodução da primeira fase do ciclo de violência (tensão), em especial no que diz respeito a técnica de inversão de culpa (o homem acusa a mulher de ser responsável por sua própria morte), devem ser combatidas e rechaçadas, denunciadas como falaciosas e inaceitáveis para os atuais padrões culturais e sociais. (DIRETRIZES NACIONAIS FEMINICIDIO... 2016, p. 100)

Obviamente que a adoção de uma estratégia de acusação exige muito mais atenção quando se tratam de crimes de homicídio, em face das peculiaridades do procedimento dos crimes de competência do Tribunal do Júri. Quando se trata de feminicídio, os cuidados devem ser redobrados, pois não é incomum que a defesa use e abuse de preconceitos e estereótipos como técnicas para conseguir a absolvição ou a redução da pena. Assim, apesar do recomendado pelas Diretrizes Nacional do Feminicídio ${ }^{47}$, não é necessário que a denúncia pormenorize, de forma detalhada, cada fato que diga respeito ao ciclo de violência.

Vale a lição de Lyra (1943, p. 52), conforme citado por Bonfim (2012, p. 109-110), de que a "denúncia deve mesmo ser um relato sucinto", e que a "denuncia não é arrazoado, nem parecer. Mesmo como peça narrativa, sob reserva de modificação e esclarecimento, limita-se a positivar claramente a espécie, permitindo o perfeito exercício da defesa." Assim, como ensinou Bonfim (2012, p. 110), a denúncia "é narrativa dos elementos substanciais [...] sem adjetivação desmedida, sem o perdimento do verbo na exposição de

\footnotetext{
47 "O ponto de partida deve-se dar na comprovação da morte ou de sua tentativa, a fim de configurar a existência de um feminicídio consumado ou tentado. No que diz respeito ao componente fático, é necessário que a denúncia pormenorize, de forma clara e detalhada, cada um dos fatos dotados de relevância jurídica, para demonstrar as acusações imputadas e a responsabilidade dos agentes. É igualmente importante que a denúncia apresente informações completas sobre o perfil da vítima e sobre o(a) indiciado(a), de modo a evidenciar as razões de gênero e outros fatores que tenham afetado as condições de vulnerabilidade em que a vítima se encontrava e que possam ter influenciado a prática do crime - como a idade, raça/cor ou etnia, condição socioeconômica sua orientação ou identidade sexual, além do relacionamento entre a vítima e seu agressor." (DIRETRIZES NACIONAIS FEMINICIDIO... pág. 95)
} 
detalhes. É peça seca, enxuta, somente com os requisitos legais.". É importante sempre ter em mente que a denúncia deve manter uma pretensão de se amoldar às circunstâncias do processo. Portanto, não se deve descrever detalhes em demasia, que, ao longo das fases processuais podem se perder, ao não serem confirmados, fragilizando a tese de acusação.

É necessário conceber a denúncia com abertura suficiente para uma concepção holística das narrativas processuais, em que os detalhes úteis podem ser demonstrados em plenário de julgamento pelo júri e ao mesmo tempo estejam mencionados, ainda que indiretamente na denúncia ${ }^{48}$. Claro que, ao assumir a perspectiva de gênero, basta relatar, se for o caso, a existência de indícios do ciclo da violência e do comportamento controlador, possessivo, ciumento, etc., do agressor, sem maiores adjetivações ou detalhes que possam comprometer a tese acusatória.

\section{CONCLUSÃO}

O feminicídio é crime de homicídio qualificado de natureza objetiva, em que o agente comete o crime contra mulher, em razão do sexo feminino, em situação de violência doméstica e familiar; ou por menosprezo ou discriminação à condição de mulher.

Apesar de alguma divergência quanto a natureza jurídica do femi-

\footnotetext{
48 Segundo Taruffo (2016, p. 85-86), "O tema da história completa está na base da concepção holística das narrativas processuais; proposta, em contraste com os ordenamentos analíticos ou atomista em matéria de provas, sobretudo no âmbito da psicologia social, refere-se especificamente ao modo com que se supõe que os júris formulem suas decisões sobre fatos. As pesquisas empíricas em particular por Bennet e Feldman e por Pennington e Hastie parecem confirmar a conclusão de que os júris não se empenham em análises detalhadas dos fatos e das provas que lhes competem, mas usam tipicamente histórias, com o escopo de organizar os elementos de prova apresentados em audiência. Portanto, os jurados chegam às suas conclusões sobre os fatos valorando a plausibilidade de histórias completas relativa aos próprios fatos, sem desenvolver qualquer raciocínio analítico sobre circunstâncias específicas ou sobre elementos singulares de prova. Em outras palavras, os júris norte-americanos estabelecerem a verdade dos fatos essencialmente construindo e confrontando narrativas, ao invés de fazê-lo valorando criticamente as informações oferecidas pelas provas. Há, ainda, quem diga que não só isso ocorre, como - aliás - é um método positivo e recomendável para a formulação das decisões sobre fatos." (TARUFFO, 2016, págs. 85-86). Se houver detalhes em demasia na denúncia, que, por sua vez não foram confirmados em instrução, pode haver comprometimento da concepção holística da tese acusatória, enfraquecendo o poder de convencimento, e, consequentemente, estimulando a impunidade.
} 
nicídio, os tribunais, e, em especial, o Supremo Tribunal Federal e o Superior Tribunal de Justiça, já formularam indicativos no sentido de tratar a violência contra a mulher como violência estrutural e institucionalizada. Desse modo, espera-se que o feminicídio seja tratado como circunstância qualificadora do crime de homicídio da qual não dependa dos motivos determinantes do crime, ou seja, que o feminicídio possa coexistir com os motivos de forma independente. Assim, ainda que o júri reconheça o homicídio privilegiado, nada impediria o reconhecimento do feminicídio, tratando ambas as situações com seu devido respeito.

Não são raros os casos em que os júris deixam de reconhecer a torpeza ou a futilidade dos crimes praticados contra a mulher, mas acolhem a tese de feminicídio, assegurando um tratamento mais justo. ${ }^{49}$

Quando explicada a natureza jurídica objetiva do feminicídio, expostos os dados relativos à violência contra a mulher e desenvolvida uma narrativa holística dos fatos para fazê-los entender que o feminicídio é um crime grave, é possível fazer justiça e combater a percepção de que o sistema de justiça não tem a capacidade de responder em tempo razoável para dissuadir a violência contra a mulher.

Contudo, é preciso capacitar os profissionais do júri para que incorporem a perspectiva de gênero nos casos de feminicídio. Também faz-se necessário que se desenvolvam estratégias para que o sistema de proteção à mulher também sirva às Vara do Tribunal do Júri.

A efetividade da Lei Maria da Penha (Lei n 11.340, de 2006) também passa pelo Tribunal do Júri. Os promotores do júri possuem uma responsabilidade enorme no combate ao feminicídio, reafirmando a verdade e colaborando para a promoção da justiça.

\footnotetext{
49 No Processo $n^{\circ}$ 0037797-43.2015.8.06.0001, que tramitou na $4^{\text {a }}$ Vara do Júri da Comarca de Fortaleza/CE, os jurados acolheram a circunstância qualificadora de feminicídio, depois de rejeitarem o motivo torpe (ciúmes). Assim, caso não fosse o feminicídio, a morte da mulher, ex-companheira do réu, redundaria em crime de homicídio simples, com pena de 6 (seis) anos em regime semi-aberto, enquanto que o réu acabou sendo condenado à pena de 12 (anos) reclusão em regime inicialmente fechado. O Ministério Público recorreu em face da dosimetria da pena.
} 


\section{CONCEPT AND LEGAL NATURE OF THE FEMINICIDE}

\section{ABSTRACT}

Femicide is a crime of murder in the first degree of objective nature, committed against woman, for reasons of the female sex. Femicide was created to combat domestic and family violence against women and contempt or discrimination against women. Femicide results from the ideology that chauvinism and power stand out as instruments of domination and subjugation of woman by man. Brazil is one of the most deadly countries in the world. Femicide is an objective circumstance because it is a woman's personal situation or quality. Femicide is not confused with the motives of crime, since it is structural and institutionalized violence. The Public Prosecutor's Office must incorporate the gender perspective in cases offeminicide to reinforce the effectiveness of the Maria da Penha Law (Law 11.340, of 2006).

Key-words: Feminicide. Public Prosecutor's Office. Trial by jury.

\section{REFERÊNCIAS}

A VIOLÊNCIA DOMÉSTICA FATAL: o problema do feminicídio íntimo no Brasil. FGV DIREITO SP, 2015. Disponível em:<http://www.pnud.org.br/ arquivos/publicacao_feminicidio.pdf>. Acesso em: 25 abr. 2017.

BRASIL. Lei 11340 de 7 de agosto de 2006. Diário Oficial da União, Brasília [DF], 8 ago. 2006. Disponível em:<http://www.planalto.gov.br/ccivil_03/_ ato2004-2006/2006/lei/111340.htm>. Acesso em: 14 mai. 2017.

Lei 13104 de 7 de agosto de 2006. Diário Oficial da União, Brasília [DF], 10 mar. 2015. Disponível em:<http://www.planalto.gov.br/ccivil_03/_ Ato2015-2018/2015/lei/L13104.htm>. Acesso em: 22 jun. 2017.

Código Penal. Disponível em:<http://www.planalto.gov.br/ccivil_03/ decreto-lei/Del2848compilado.htm>. Acesso em: 12 jun. 2017. 
Superior Tribunal de Justiça. Recurso especial 1183378 RS 2010/0036663-8. Diário da Justiça Eletrônico, Brasília [DF], 25 out. 2011. Disponível em:<https://stj.jusbrasil.com.br/jurisprudencia/21285514/recurso-especial-resp-1183378-rs-2010-0036663-8-stj>. Acesso em: 12 jun. 2017.

Superior Tribunal de Justiça. Recurso Especial REsp 1416580 RJ 2013/0370910-1. Diário da Justiça Eletrônico, Brasília [DF], 15 abr. 2014. Disponível em:<https://stj.jusbrasil.com.br/jurisprudencia/25055291/ recurso-especial-resp-1416580-rj-2013-0370910-1-stj?ref=juris-tabs >. Acesso em: 12 jun. 2017.

Superior Tribunal de Justiça. Habeas Corpus HC 342660 / MG 2015/0300984-8. Diário da Justiça Eletrônico, Brasília [DF], 28 jun. 2016. Disponível em:<http://www.portaljustica.com.br/acordao/301619>. Acesso em: 12 jun. 2017.

Supremo Tribunal Federal. Habeas Corpus HC 52480 SP. Diário da Justiça, Brasília [DF], 08 nov. 1974. Disponível em:<https://stf.jusbrasil. com.br/jurisprudencia/710544/habeas-corpus-hc-52480-sp?ref=juris-tabs $>$. Acesso em: 28 abr. 2017.

BETTIOL, Guiseppe. Direito Penal. Campinas: Red Livros, 2000.

BITENCOURT, Cézar Roberto. Tratado de Direito Penal: parte especial, vol. II. 17. ed. revista. ampliada e atualizada. São Paulo: Saraiva, 2017.

BONFIM, Edilson Mougenot. Júri: do inquérito ao plenário. 4. ed. São Paulo: Saraiva, 2012.

CAPEZ, Fernando. Curso de Direito Penal. Vol. 2, 17. ed. São Paulo: Saraiva, 2017.

CASARA, Rubens R. R. Mitologia Processual Penal. São Paulo: Saraiva, 2015.

CUNHA, Rogério Sanches; e PINTO, Ronaldo Batista. Tribunal do Júri: procedimento especial comentado por artigo. Salvador: JusPodivm, 2015. 
DIRETRIZES NACIONAIS FEMINICÍDIO: investigar, processar e julgar, com perspectiva de gênero, as mortes violentas de mulheres. Projeto de Implementação do Protocolo Latino-americano para investigação das mortes violentas de mulheres por razões de gênero no Brasil. Realização da Entidade das Nações Unidas para a Igualdade de Gênero e o Empoderamento das Mulheres - ONU Mulheres e de outras entidades. Brasília, 2016. Disponivel em: <http://www.agenciapatriciagalvao.org.br/dossies/ feminicidio/diretrizes-nacionais/>. Acesso em: 25 abr. 2017.

\section{DIRETRIZES NACIONAIS DE INVESTIGAÇÃO CRIMINAL COM PERS-} PECTIVA DE GÊNERO: Princípios para atuação com perspectiva de gênero para o Ministério Público e a segurança pública do Brasil. Coleção Documentos de Política n. 28. Madrid, mar. 2016. <http://www.compromissoeatitude.org. $\mathrm{br} /$ diretrizes-nacionais-de-investigacao-dos-crimes-de-violencia-domestica-com-perspectiva-de-genero/>. Acesso em: 25 abr. 2017.

ELUF, Luiza Nagib. A Paixão no Banco dos Réus. São Paulo: Saraiva, 2014.

\section{ENUNCIADOS da Comissão Permanente de Combate à Violência} Doméstica e Familiar contra a Mulher. Disponível em: <http://www. compromissoeatitude.org.br/enunciados-da-copevid-comissao-nacional-de-enfrentamento-a-violencia-domestica-e-familiar-contra-a-mulher/>. Acesso em: 25 abr. 2017.

FERNANDES, Millôr. Millôr definitivo: a bíblia do caos. Porto Alegre: L\&PM, 2016.

FERNANDES, Valéria Diez Scarance. Lei Maria da Penha: o processo penal no caminho da efetividade, abordagem jurídica e multidisciplinar (inclui lei de feminicídio). Atlas: São Paulo, 2015.

FRAGOSO, Heleno Cláudio. Lições de Direito Penal: parte geral. 11. ed., rev. Rio de Janeiro: Forense, 1987.

GRECO, Rogério. Curso de Direito Penal: parte especial. Vol. II. 14. ed. Niterói/RJ: Editora Impetus, 2017.

HUNGRIA, Nélson. Cometários ao Código Penal: Vol. V (arts. 121 a 136). 
2. ed. rev., 1953.

JESUS, Damásio E. de. Direito Penal: $2^{\circ}$ volume - parte especial. São Paulo: Ed. Saraiva, 1998.

LYRA, Roberto. Como julgar, como defender, como acusar. Rio de Janeiro: José Konfino editor, 1975.

MIRABETE, Julio Fabbrini. Código Penal Interpretado. São Paulo: Atlas, 1999.

NUCCI, Guilherme de Souza. Manual de Direito Penal. Rio de Janeiro: Forense, 2015.

PERCEPÇÃo da sociedade violência e assassinatos de mulheres. Disponível em:<http://agenciapatriciagalvao.org.br/wp-content/uploads/2013/08/livro_pesquisa_violencia.pdf>. Acesso em: 25 abr. 2017.

ROSA, Antônio José Miguel Feu. Direito Penal: parte especial. São Paulo: Revista dos Tribunais, 1995.

SAPORI, Luís Flávio e SOARES, Gláucio Ary Dillon. Por que Cresce a Violência no Brasil. Belo Horizonte: Autêntica Editora, Editora PUC Minas, 2014.

TARUFFO, Michele. Uma simples verdade: o juiz e a construção dos fatos. Trad. Victor de Paula Ramos. São Paulo: Marcial Pons, 2016.

VASCONCELOS, Arnaldo. Teoria da Norma Jurídica. 6. ed. São Paulo: Malheiros Editores, 2006.

VERÍSSIMO, Luiz Fernando. As Mentiras Que As Mulheres Contam. Rio de Janeiro: Objetiva, 2015.

WAISELFISZ, Julio Jacobo. Mapa da Violência 2015: homicídio de mulheres no Brasil. Disponivel em:<http://www.mapadaviolencia.org.br/pdf2015/ MapaViolencia_2015_mulheres.pdf>. Acesso em Brasília: 2015.Acesso em: 25 abr. 2017. 